\title{
A Study of Vascular and Liver Disease in Dogs Experimentally Induced Diabetes
}

\author{
Katsumi AOYAMA \\ The 3rd Department of Internal Medicine, Nagoya University School of Medicine \\ (Director : Professor Kozo Yamada)
}

It is a well-known fact that an incidence of vascular and/or liver disease is considerably high in case of diabetes; however, the relationship of diabetes to vascular and liver disease is not yet fully understood. The present study was made to investigate the relationship between vascular \& liver disease and diabetes, using pancreatectomized dogs fed by high fat diet over a long time.

The results were as follows,

1) In case of total pancreatectomy, fasting hyperglycemia continued, and serum lipid levels like cholesterol, lipid-P and N.E.F.A. showed also a rise, and plasma insulin like activity was nearly zero. However, there was no marked difference of the said components between controls and subtotally pancreatectomized dogs.

2) In a short time after pancreatectomy pyridoxin phosphorylation was disturbed, then returned to normal by the administration of insulin. However, that was not recovered even by administration of insulin long after the pancreatectomy.

3) In case of total pancreatectomy, the microscopic findings revealed edema and fibrous thickening of the intima, rupture of the internal elastic lamella, and calcification and hyalinization of the media of the aorta. Two out of fifteen dogs showed stenosis of the vessels in the heart muscle.

4) Electrocardiogram revealed abnormality in 50 per cent of diabetic dogs, which wos mostly noted in ST and $\mathrm{T}$ waves.

5) In case of total pancreatectomy, liver function was markedly disturbed, and microscopic findings showed considerable fatty metamorphosis, abnormal arrangement of liver cells, and focal hemorrhage \& necrosis.

These results revealed that high fat loading diet under insulin deficiency play a role of incidence and development of vascular and liver disease. These facts seem to infer the importance of studying the relationship of diabetes mellitus to vascular and liver disease.

(pp. 872 884) 


\title{
実験的糖尿病犬に於ける血管障害 及び肝障害に関する研究
}

\author{
名占屋大学医学部山田内科教室（主任 山田弘三教授） \\ 青 山 克
}

(昭和 40 年 2 月 19 日受付)

\section{I 緒 言}

糖尿病患者に於ける動脈硬化症の発生頻度は極めて高率である。従来, 糖尿病にとつて最も恐れられてい た昏睡, 感染等はインスリンの発見と抗生物質なぞ化学療法の進歩の結果, 今日一応解決されたが，てれに 代つて動脈硬化症を中心とする血管障害が問題にされる様に成つた，Joslin ${ }^{11}$ にれば糖尿病の死因の $80 \%$ が何らかの血管障害によるものであると言う。

糖尿病の際の血管障害の主な病変は, 糖尿病性網膜症, 督症及び他の動脈硬化性変化である. 糖层病性動 脈硬化は糖尿病に特徵的な性格を持つとした報告もあるが22,3)，一方てれを否定するものもある．更にはそ の成因に関しても，脂質代謝異常はもとより各方面から検討されているが尚不明の点が多い現状である.

他方, 糖尿病患者では霬々肝機能障害が認められ, 糖尿病に於ける肝障害について多くの報告をみるが, その発現頻度及び病因については必ずしも見解の一致を見ていない，又，近年糖尿病と肝硬变との命併頻度 が高いとの報告も有るが，両者の因果関係についても議諭の多いとてろである.

この様に糖尿病時の血管障害及び朋障害に及ぼす原因的要因が何れにあるか，例えば，Control の良否に よるのか, 脂質代謝異常の結果招来されるのか，又，インスリンの欠芯によるものなのか等は，未だ明らか にされていない.

私は今回，膵全摘及び車全摘大に高脂肪食を投与し比較的脣期間飼育することによつて，糖尿病状態が血 管障害及び肝障書の発生進展に果す役制を検索し新たな知見を得たので報告する。

\section{II 実験材料及び実験方法}

实験動脈は 2 乃至 4 オの雑種正常犬で体重 8 乃至 $10 \mathrm{~kg}$ ののを選んだ。オーロパンソーダ静脈麻酰のも とに開腹し膵摘出を行なつた，その際，膵頭部の腸管附着部は鈍的剝離により，膵全摘出を行なつた群は全 摘出犬とし, 大膵管領域の小断片を残した群は亜全摘出犬とし, 対照犬を加えて三群に大別した。乙れら各 群何れも一頭につき, 米飯700gm, 鯨肉 $100 \mathrm{gm}$, 豚ラード $20 \mathrm{gm}$ (蛋白質 $3 \sim 4 \mathrm{gm} / \mathrm{kg}$, 脂肪 $3 \sim 4 \mathrm{gm} / \mathrm{kg}$ ) を朝夕二回に分けて与光，5 ケ月以上８ケ月に亘つて飼育した，各食慨にはパンクレアチン，デァスターゼ， ビオフェルミン，アミラーゼ，リパーゼ，プロテアーゼ等の消化醃素及びメチオニン，複合ビタミンを混合 して投与した。, 又, 各群については，梁腹時血糖伹，コレステロール，非ェステル型脂肪酸（以下 NEFA と略す）血清脂質燐（以下 Lipoid-P と略す）心電図（以下 ECG と略す）を経時的に観察し 5 万至 8 ケ 月後に血中インスリン様活性（以下 ILA と略す） $\mathrm{VB}_{6}$ 活性化能を測定し病理組織学的検索を行なつた。 尚, 膵全摘犬群には糖尿病状態が Poor Control の状態で而も生命を維持するに要する最少量のレンテイン スリンを毎日或いは隔日にその時の血糖值に応じて与えた。尚, 諸臟器の病理組織学的検索には屡殺直後の ものを用いた，採血は肘静脈より行ない，次に示す方法で各種血清学的検查の測定を行なつた。

i) 血糖值 Hagedorn-Jensen 氏法 ${ }^{7}$

ii) NEFA Dole 氏法 ${ }^{8)}$ 
iii）コレステロール Kilianin 柴田氏変法 ${ }^{9)}$

iv) Lipoid-P Fiske Sabarrow 氏法 ${ }^{10}$

v) $\mathrm{VB}_{6}$ 活性化能，市原氏法 ${ }^{11}$

vi）血中インスリン様活性

教室の柴田 $\left.{ }^{12}\right)$ が発表した微量インスリン定量法

\section{III 実 験 成 績}

\section{a）空腹時血糖値}

膵全摘犬群では術後より急激な血糖上昇を示し，放置すれば間もなく死亡するのでインスリンを投与して， 空腹時血糖值が200〜 400mg/diの範囲内に維持される様に調整した. 覀全摘大では術後の高血糖はみられず 対照犬と同様に $100 \mathrm{mg} / \mathrm{dl}$ 前後の血糖值を示すに過ぎないが (Fig. 1)，ブドウ糖負荷試験（50\%ブドウ糖 1 $\mathrm{ml} / \mathrm{kg}$ 静注法）で対照犬と比べて明らかな耐糖能の低下を示した(Fig. 2).

Fig. 1. Blood Sugar Levels in Diabetic Dogs

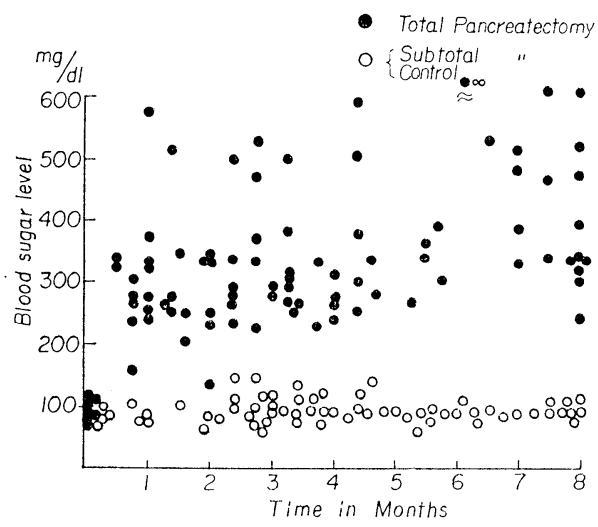

Fig. 2. Glucose Tolerance Test of Normal and Subtotally Pancreatectomized Dogs

Control

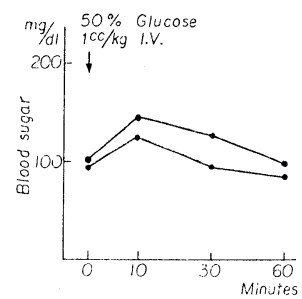

Subtotally pancreatectomized god

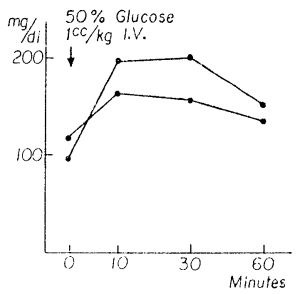

\section{b）血清コレステロールの推移}

膵全摘犬では術後より血清コレステロールの上昇を認め以後 $200 \mathrm{mg} / \mathrm{dl}$ 以上 $350 \mathrm{mg} / \mathrm{dll}$ に至り特には $400 \mathrm{mg} / \mathrm{dll}$ に及ぶ高值を持続している。亜全摘犬では $150 \mathrm{mg} / \mathrm{dl}$ 以上 $200 \mathrm{mg} / \mathrm{dl}$ と低值であり対照犬のそれ と殆んど差は無い(Fig. 3 ).

c) 非エステル型脂肪酸 (NEFA) の推移

膵全摘犬では術後 3 週頃より上昇傾向を示し, 以後 8 ケ月に亘る迄 1500 以上 $2500 \mu \mathrm{Eq} / 1$, 洔に は $3000 \mu \mathrm{Eq} / 1$ 以上にも及ぶ高值で経過する。亜 全摘犬では全期間を通じて $800 \sim 1500 \mu \mathrm{Eq} / \mathrm{l}$ と低 く，対照犬のそれと略々，同じ值或いはそれより 稍々，高值を示すに過ぎない(図4).

\section{d）血中脂質燐の推移}

萃全摘犬では術後 2 ケ月頃迄は $10 \sim 15 \mathrm{mg} / \mathrm{dl}$ で亜全摘犬及び対照犬と著明な差は㤠められなか つたが，2 ケ月以後に至り全摘犬では漸次上昇傾 向を辿り 8 ケ月では20〜 35mg/dl と極めて高值を
Fig. 3. Serum Cholesterol in Diabetic Dogs

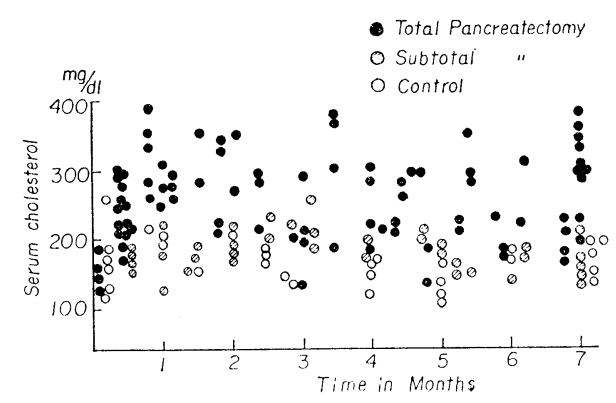


Fig. 4. Plasma NEFA in Diabetic Dogs

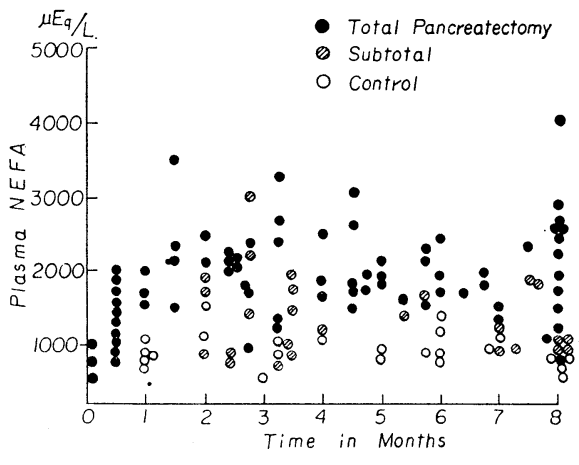

Fig. 5. Serum Phospholipid in Diabetic Dogs

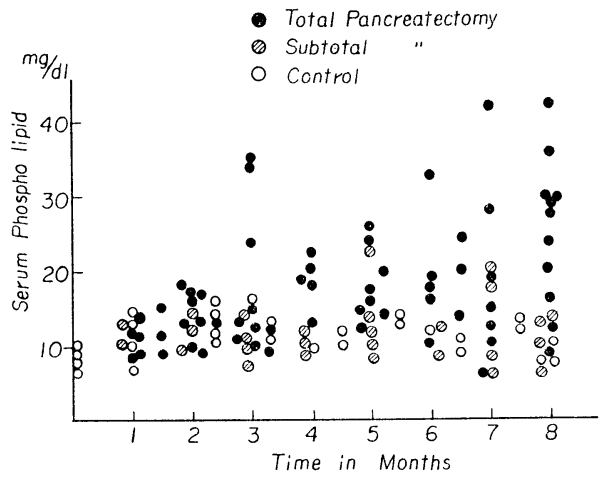

示した，亜全摘犬及び対照犬では 2 ケ月以後も尚 $10 \mathrm{mg} / \mathrm{dl}$ 前後の优をもつて経過している，尚曲全摘犬では 稍々高值を示す傾向がみられた(Fig. 5 ).

e) 膵摘犬に於ける心電図学的変化

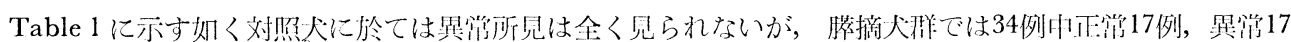

Table 1. E.C.G. in Diabetic Dogs

\begin{tabular}{l|c|l|c|c}
\hline & No. & Findings of E.C.G. & No. & \\
\hline Control & \multirow{2}{*}{7} & Normal & 7 & \\
group & & Abnormal & 0 & \\
\hline $\begin{array}{l}\text { Group performed } \\
\text { pancreatectomy }\end{array}$ & \multirow{3}{*}{34} & Normal & 17 & \multirow{2}{*}{ ST, T change 17 } \\
\hline
\end{tabular}

Prognosis of abnormal E.C.G.

\begin{tabular}{l|l}
\hline Temporal change & 5 \\
Permanent change & 8 \\
Unknown & 4 \\
\hline
\end{tabular}

例であり, 50\%に何らかの買常所見が浔められた，其の変化は主として ST, T の変化であり ST の低下，T の平低及び陰性 $\mathrm{T}$ とて涩められた，内1例に期外収縮を伴つたものがみられた，膵摘犬の心電図で異常を 認めたもの17例中その変化が一過性のものは 5 例，恒久性の変化を示したもの 8 例であつた. Fig. 6 は膵摘 犬の術前及び術後 8 ケ月（その閏 poor control の状態で維持）に於ける ECG の一例を示したものである.

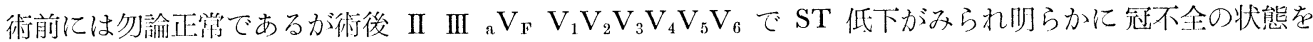
示している.

\section{f）膵摘犬に於ける $V B_{6}$ 活性化能}

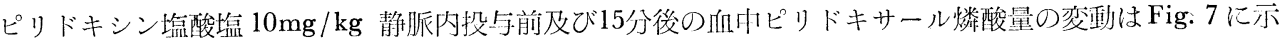
す如くである。

対照犬ではピリドキサール燐酸量の增加は顕著でその前值に対する上昇率は $188.6 \%$ と高い. 一方膵摘後 6〜8 ケ月閒に亘り高度の糖尿病状態下に飼育せられた犬ではピリドキシン注射後のピリドキサール燐酸量 の増加は殆んどみられずその前值に対する上昇率は $102.4 \%$ と低い。またピリドキシン $10 \mathrm{mg}$ とインスリン $0.1 \mathrm{u} / \mathrm{kg}$ 在同㭙に静脈内注射すれば，対照犬ではピリドキサール燐酸晕の增加はピリドキシン単独投与の 
場合と同じく顕著で上昇率は $187.2 \%$ で ある。これに反し，膵摘犬ではインスリ ンを併用してもビリドキサール燐酸量の 増加は認められず，上昇率も $107.2 \%$ と 低い。即ち, 長期飼育膵摘犬では $\mathrm{VB}_{6}$ 活 性化能の低下は最早不可逆的で, 子想に 反してインスリンの附燐能活化効果も発 揮されるに至らない。

これに反して膵摘後 96 時間の短期膵摘 犬では，Fig. 8 亿示す如くピリドキシン $10 \mathrm{mg}$ 静脈内負荷した場合，刘照犬では 15分後にピリドキサール燐酸量は増加し 前值に対する上昇率は $188.6 \%$ と高いが， 膵摘犬ではピリドキシン単独負荷の場合 にはピリドキサール燐酸量の増加は極め て低く前值に対する上昇率は $113.7 \%$ に 過ぎない.しかしながらインスリン 0.1 $\mathrm{u} / \mathrm{kg}$ を同時静脈内負荷すると膵摘犬で

Fig. 7. Canine Serum Pyridoxal Phosphate Long Term after Pancreatectomy (6 8 Months after Pancreatectomy)
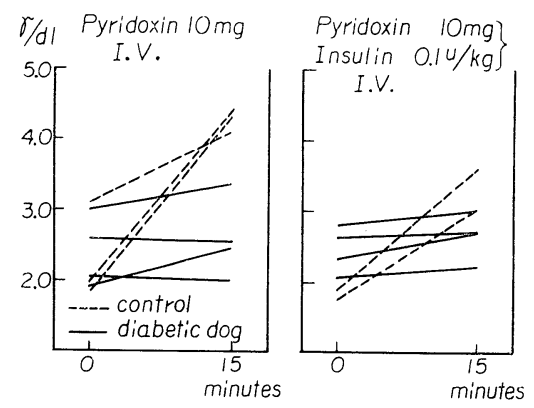

(increasing ration of before and after Pyridoxin injection)

\begin{tabular}{|l|l|l|l|}
\hline Control & $188.6 \%$ \\
\hline Diabetic dog & $102.4 \%$ \\
\hline
\end{tabular} \begin{tabular}{|l|l|}
\hline Control & $187.2 \%$ \\
\hline Diabetic dog & $107.2 \%$ \\
\hline
\end{tabular}

Fig. 6. E.G.G. in Diabetic Dogs

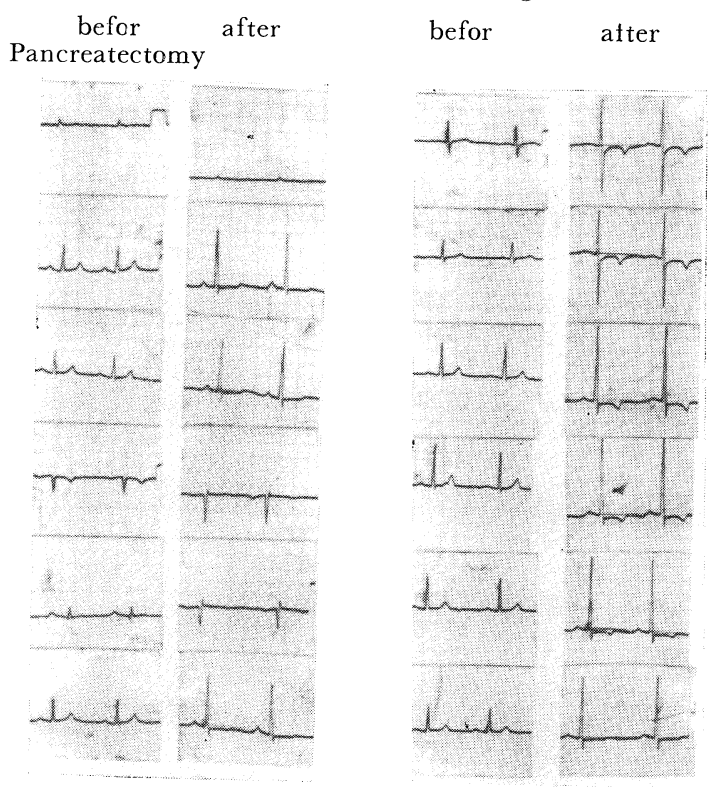

Fig. 8. Canine Serum Pyridoxal Phosphate Short Term after Pancreatectomy (96 hours aftar Pancreatectomy)
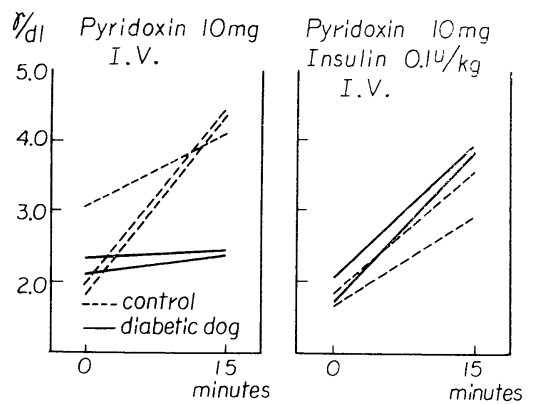

(increasing ration of before and after Pyridoxin injection)

\begin{tabular}{|l|l|l|l|}
\hline Control & $188.6 \%$ \\
\hline Diabetic dog & $113.7 \%$ \\
\hline
\end{tabular}

もその上昇率は $205.3 \%$ と完全に回復する。即ち短期膵摘犬の場合， $\mathrm{VB}_{6}$ 活性化能の障害は存在するがその 障害は未だ不可逆の段階に達していない.

g) 膵摘犬に於ける血中インスリン樣活性 (ILA)

脺全摘後 6 〜 8 ケの犬の血中 ILA を測定するにFig. 9 亿示す如く, 膵全摘犬群では殆んど皆無に近い 血中 ILA を示した。一方两全摘犬では $0.8 \sim 1.2 \mathrm{mu} / \mathrm{ml}$ を示し, 正常犬 $(1 \sim 1.5 \mathrm{mu} / \mathrm{ml})$ に近い血中 ILA レベルを維持している.

\section{h）膵摘犬に於ける肝機能}

萃摘後 6 〜 8 ケの肝機能は Table 2 に示す如くである. 即ち膵摘犬では朋機能の異常を有するもの18 例中 8 例 $44 \%$ にられた。 この表からも明らかな如く刘照犬ではセファリンコレステロール絮状反応 (CGF) で 5 例中 2 例，血清トランスアミナーゼ(G.O.T.)で 5 例中 1 例に異常を認めたにすぎなかつたが，膵摘犬で 
は血清ビリルビンの増加はみられなかつたが血清 膠質反応及び血清トランスアミナーゼの増加が顕 著である。其のほかアルカリフォスファターゼ及 びコレステロールの増加が認められた。

\section{i) 膵摘犬の病理組織学的所見}

血管の変化を中心に検索したがその結果は Table 3 に示す如くである.

心筋肉に於ける血管の栓塞は膵摘犬，対照犬共 にみられなかつたが，膵摘犬に於いて15例中 2 例 飞心筋内間質血管の硬化像がみられた。この例は EGG に於いて明らかな冠不全の 状態を示してい たものである.

冠動脈の硬化像は膵摘犬，対照犬共にみられな かつた。主たる変化は大動脈にみられその組織像 は Table 4 に示す様に動脈硬化の初期像に一致 する。

大動脈の内膜下浮腫（所謂 intimal odema と 呼ばれるもの) 内膜下粗造化は殆んど全例にみと
Fig. 9. Plasma Insulin Llike Activity in Total Pancreatectomy and Control

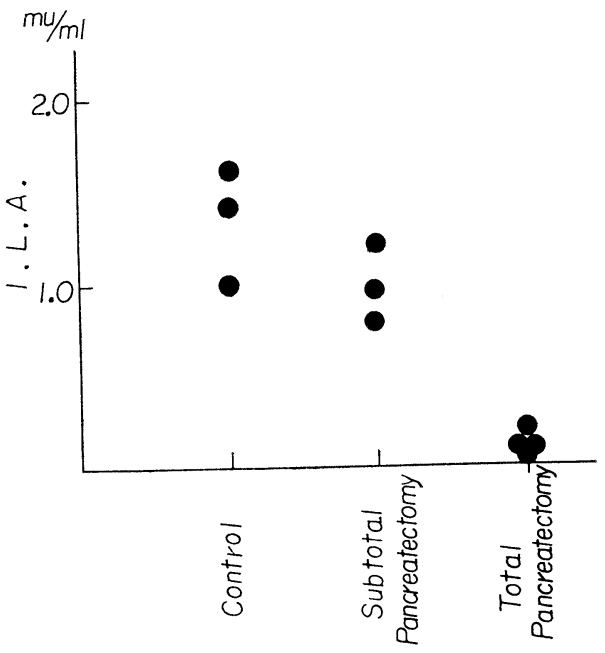

Table 2. Liver Function in Pancreatectomized Dogs

\begin{tabular}{|c|c|c|c|c|c|c|c|c|c|c|c|}
\hline & & $\begin{array}{l}\text { Total } \\
\text { protein }\end{array}$ & $\mathrm{A} / \mathrm{G}$ & T.T.T. & $\mathrm{CCF}$ & $\begin{array}{l}\text { Total } \\
\text { bilirubin }\end{array}$ & $\begin{array}{l}\text { Alkali } \\
\text { P-ase }\end{array}$ & $\begin{array}{l}\text { Inorg- } \\
\text { anic-P }\end{array}$ & G-O-T & G-P-T & $\begin{array}{l}\text { Choles- } \\
\text { terol }\end{array}$ \\
\hline 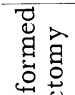 & Normal & 16 & 12 & 18 & 12 & 18 & 13 & 4 & 9 & 11 & 10 \\
\hline 苛总 & $\begin{array}{l}\text { Abnor- } \\
\text { mal }\end{array}$ & 2 & 4 & 0 & 6 & 0 & 5 & 12 & 9 & 7 & 8 \\
\hline 0 & Normal & 5 & 5 & 5 & 3 & 5 & 5 & 5 & 4 & 5 & 5 \\
\hline ¿ర & $\begin{array}{l}\text { Abnor- } \\
\text { mal }\end{array}$ & 0 & 0 & 0 & 2 & 0 & 0 & 0 & 1 & 0 & 0 \\
\hline
\end{tabular}

められた。一部では更に中膜の硝子化及び石灰化像を認めたが，石灭化像は Kossa 氏硝酸銀法で Ca 沈着 であるととを確証し得た。これは人動脈硬化症の Menckeberg 型に相当する。而対照犬では内膜下に軽 度の浮腫を認めるものもあつたが，その変化は膵摘犬に比較して明らかに軽度であつた. Fig. 10は対照犬の 大動脈 (PAS 染色) を示し動脈硬化像は認められない.

然るに膵摘犬では Fig.11亿示す如く（H.E. 染色）大動脈の内膜粗造化浮腫が認められる.

Fig. 12は膵摘犬の大動脈内膜の著明な肥厚例を示しFig.13は大動脈内膜の石灰化を示す.

Fig. 14は特殊染色（Kossa 氏硝酸銀法）によるCa 沈着を示し，Fig.15では（Verhoeff の弾力繊維染色法） 弾力線維の断裂像が認められる.

また一部には心筋間質内小血管の内膜肥厚及び管腔㹨小化がみとめられ Fig. 16，侍には Fig. 17 の如く 大動脈内膜の肥厚及び該部に於ける出血像を認めたものもある. 
Table 3. Histological Changes in Pancreatectomized Dogs

\begin{tabular}{|c|c|c|c|c|c|c|c|c|c|c|}
\hline & & \multicolumn{2}{|c|}{ Heart } & \multirow[b]{2}{*}{$\begin{array}{l}\text { Corona- } \\
\text { ry } \\
\text { sclerosis }\end{array}$} & \multirow[b]{2}{*}{$\begin{array}{l}\text { Sclerosis } \\
\text { of Aorta }\end{array}$} & \multirow{2}{*}{\begin{tabular}{|l|} 
Kidney \\
Sclerosis \\
of glom- \\
erulus
\end{tabular}} & \multicolumn{2}{|c|}{ Liber } & \multirow{2}{*}{$\begin{array}{l}\text { Sclerosis } \\
\text { in vesse- } \\
\text { ls of adr- } \\
\text { enal and } \\
\text { spleen }\end{array}$} & \multirow{2}{*}{$\begin{array}{l}\text { Coronar- } \\
\text { ry insu- } \\
\text { fficiency } \\
\text { in ECG }\end{array}$} \\
\hline & & $\begin{array}{l}\text { Throm- } \\
\text { bus }\end{array}$ & $\begin{array}{l}\text { Sclerosis } \\
\text { of inte- } \\
\text { nstitial } \\
\text { vessel }\end{array}$ & & & & $\begin{array}{l}\text { Cell } \\
\text { degener- } \\
\text { ation }\end{array}$ & $\begin{array}{l}\text { Fatty } \\
\text { - metamo- } \\
\text { rphosis }\end{array}$ & & \\
\hline \multirow{15}{*}{ 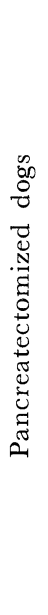 } & 1 & - & - & - & + & - & - & - & - & - \\
\hline & 2 & - & - & - & $H$ & - & + & - & - & + \\
\hline & 3 & - & - & - & + & - & - & \pm & - & + \\
\hline & 4 & - & - & - & H & - & $H$ & + & - & + \\
\hline & 5 & - & - & - & H & - & - & \pm & - & + \\
\hline & 6 & - & - & - & + & - & - & \pm & - & + \\
\hline & 7 & - & - & - & + & - & - & \pm & - & + \\
\hline & 8 & - & - & - & + & - & - & \pm & - & + \\
\hline & 9 & - & + & - & + & - & $H$ & + & - & + \\
\hline & 10 & - & - & - & \pm & - & - & + & - & - \\
\hline & 11 & - & + & - & + & - & + & - & - & + \\
\hline & 12 & - & - & - & + & - & \pm & - & - & - \\
\hline & 13 & - & - & - & + & - & \pm & - & - & + \\
\hline & 14 & - & - & - & $H$ & - & $H$ & + & - & + \\
\hline & 15 & - & - & - & $\dashv$ & - & + & - & - & + \\
\hline \multirow{5}{*}{$\begin{array}{l}\infty \\
0 \\
0 \\
0 \\
0 \\
0 \\
0\end{array}$} & 1 & - & - & - & - & - & - & - & - & - \\
\hline & 2 & - & - & - & \pm & - & \pm & - & - & - \\
\hline & 3 & - & - & - & \pm & - & \pm & - & - & - \\
\hline & 4 & - & - & - & \pm & - & - & - & - & - \\
\hline & 5 & - & - & - & \pm & - & - & - & - & - \\
\hline
\end{tabular}

Table 4. Microscopic Findings of the Aorta

\begin{tabular}{|c|c|}
\hline 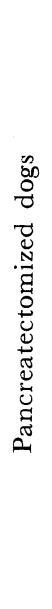 & $\begin{array}{l}1 \text { Media hyalinization }(+) \text { Calcification }(+) \\
2 \text { Intima thichning }(++) \text {, Calcification }(+) \\
3 \text { Media elastic fiber rupture } \\
4 \text { Subintimal oedema } \\
5 \text { Media necrosis and hyalinization }(+) \text {, Calcification }(+) \\
6 \text { Subintimal oedema, coarseness. } \\
7 \text { Media slight oedema } \\
8 \text { Subintimal coarseness, fibrinization (initial sclerosis) } \\
9 \text { Media coarseness. } \\
10 \text { Subintimal oedema } \\
11 \text { Media thickning, Subintimal coarseness }(+) \\
12 \text { Subintimal coarseness, slight oedema } \\
13 \text { Subintimal oedema, coarseness }(+) \text {, intimal thickning }(+) \\
14 \text { Subintimal oedema, corseness }(+) \text { deposition of hyalinsubstance } \\
15 \text { Subintimal slight oedema }\end{array}$ \\
\hline $\begin{array}{l}n \\
0 \\
0 \\
\tilde{Z} \\
0 \\
ن\end{array}$ & $\begin{array}{l}1 \text { No remarkable findings } \\
2 \text { Slight subintimal cedema } \\
3 \text { Same } \\
4 \text { Same } \\
5 \text { Same }\end{array}$ \\
\hline
\end{tabular}


Fig. 10. Control Aorta PAS. Stain $100 \times$

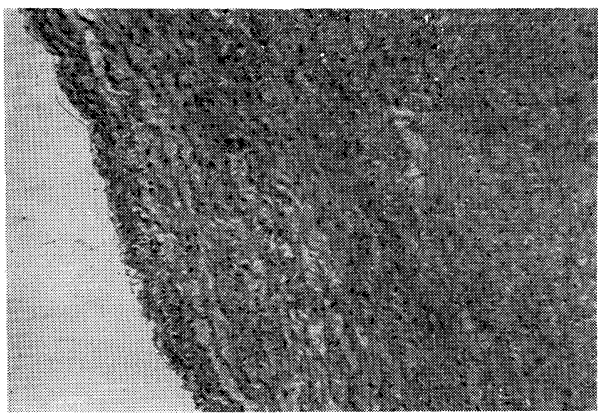

Fig. 12. Pancreatectomized dog. Thickning of aortic intima. H.E. stain $100 \times$

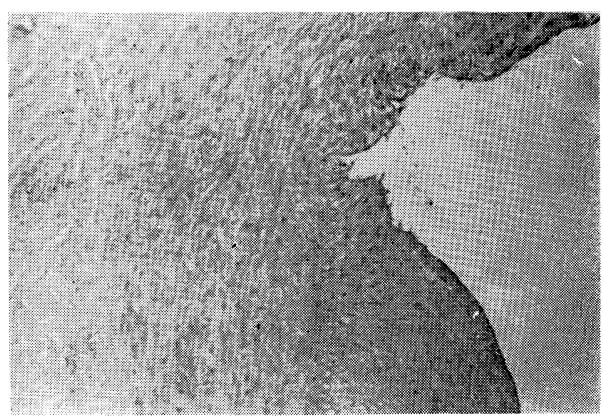

Fig. 14. Pancreatectomized dog. Kossa's silbernitrate stain for calcification of Aorta $100 x$

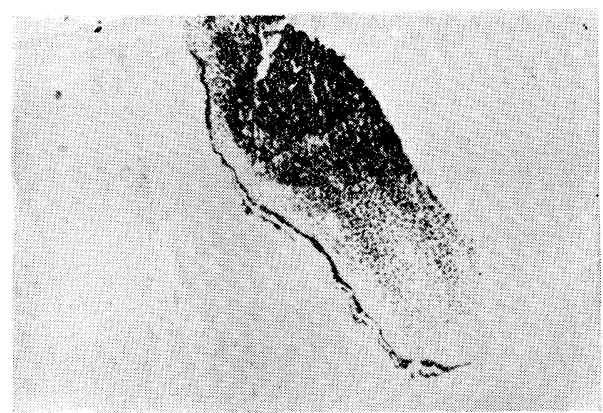

Fig. 11. Pancreatectomized Dog. Intima coarseness and edema H.E. Stain $100 \times$

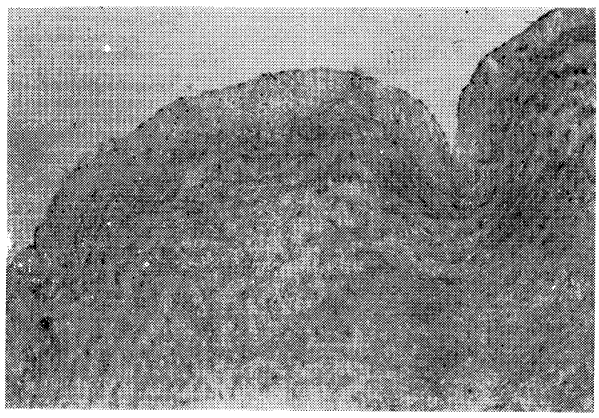

Fig. 13. Pancreatectomized dog. Calcification of Aortic intima. H.E. stain $100 \times$

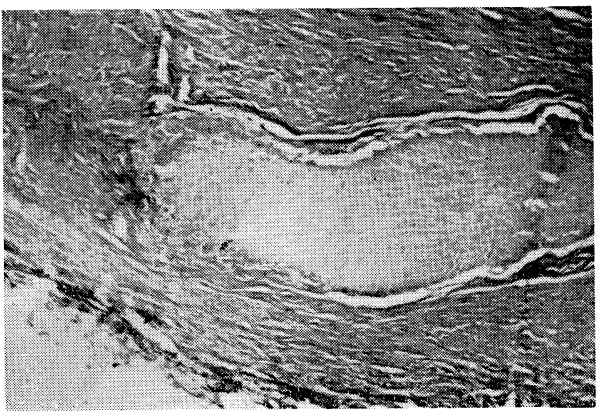

Fig. 15. Pancreatectomized Dog. By Verhoeff's elastic fiber stain. abruption of elastic fiber $100 \times$

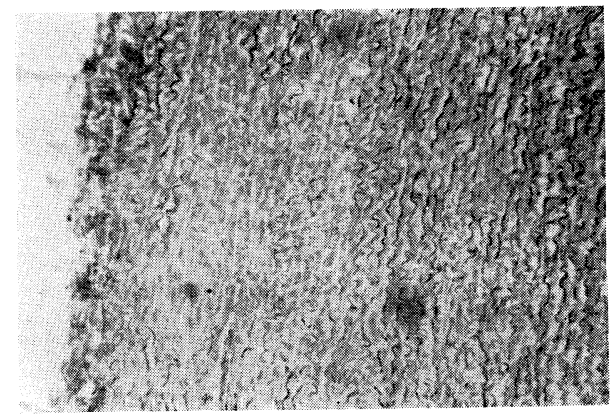

膵摘犬，対照犬共に腎糸球体及び膵の血管硬化像は認められず，又，膵摘犬では腎絲球体に於ける糖尿病 に特有とされる変化も認められなかつた。

\section{肝に於ける組織学的変化}

膵摘犬で肝細胞変性及び壊死を認めたものは15例中 8 例, 脂肪浸潤をみたものは 9 例であつた。一方対照 犬に於いても肝細胞変性を 5 例中 2 例にみとめたが，その変化は膵摘犬に比して明らかに軽度であり，脂肪 浸潤は全くみられなかつた。対照犬では Sudan III 染色により脂肪浸潤はほとんど認められず (Fig. 18)

$$
\text { 第41巻 第 } 7 \text { 号 }
$$


Fig. 16. Pancreatectomized dog. Stenosis and thickning of small vessels in heart muscle. PAS-stain $100 \times$

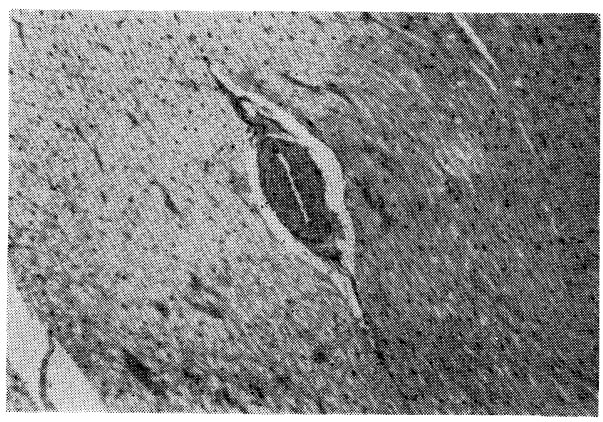

Fig. 18. Control Sadan III stain $100 \times$

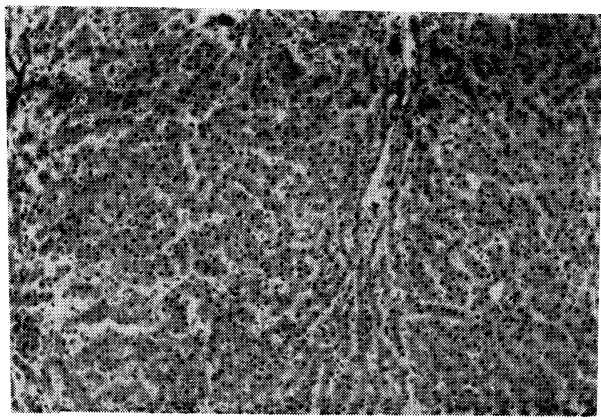

Fig. 20. Control PAS stain $100 x$

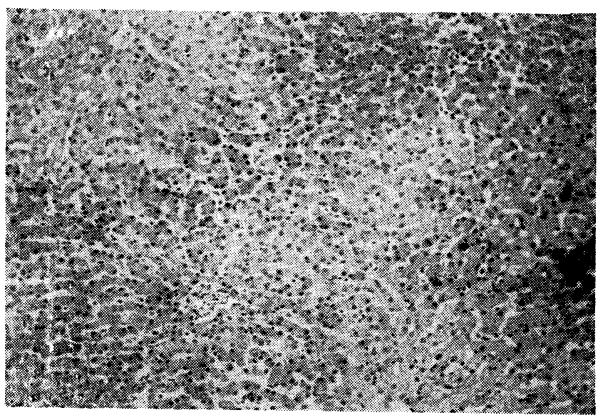

Fig. 17. Pancreatectomized dog. Hemorrhage and thickning of aortic intima. H.E stain $100 x$

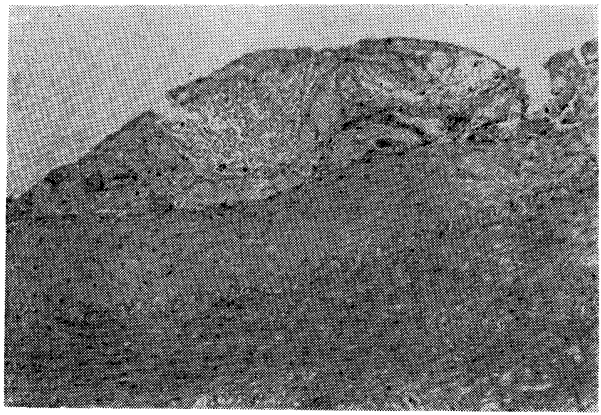

Fig. 19 Control H.E. stain $100 \times$

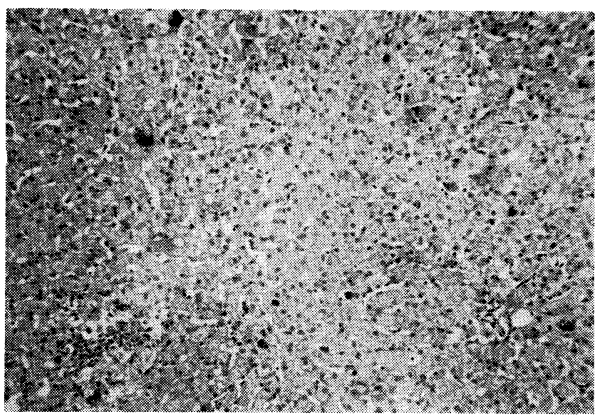

Fig. 21. Pancreatectomized dog. Central fatty deposition of liver. Sudan III stain $100 \times$

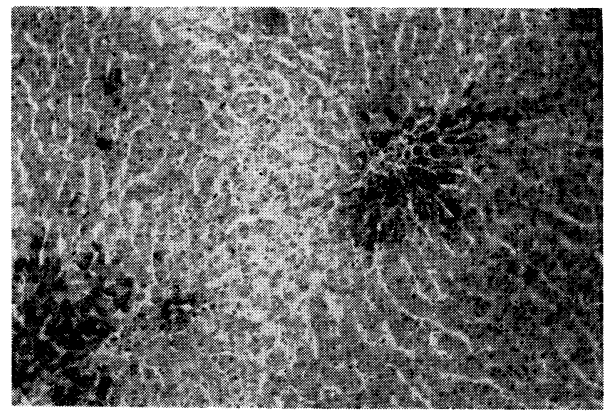

HE 染色及び PAS 染色（Fig. 19，Fig. 20）によつても肝小葉の著しい変化はみられなかつた。

然るに膵摘犬では（Fig. 21，Fig.22）強度の脂肪変性がみとめられその脂肪浸潤は中心性又はビマン性に みられる。

更に肝小葉の中心静脈を中心とした形細胞浸潤がみられ一部には肝細胞変性 及び壊死像がみられた.

(Fig. 23, Fig. 24)

尚，副腎髄質皮質は共に変化なく正常の組織像を示した。 
Fig. 22. Pancreatectomized Dog. Diffuse fatty deposition Sudan III stain $100 \times$

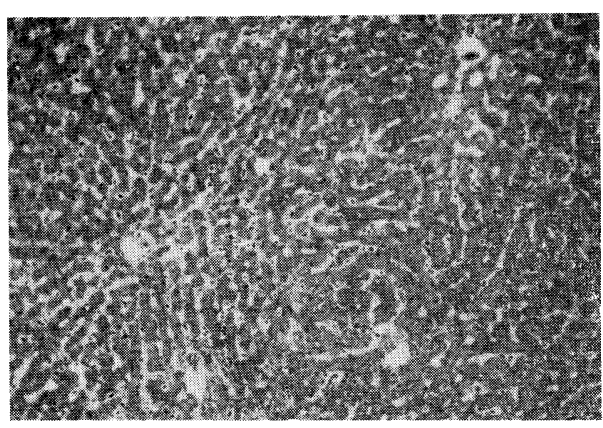

\section{IV 考}

案
Fig. 23. Pancreatectomized Dog. H.E. stain $400 \times$ degeneration and necrosis of liver cell

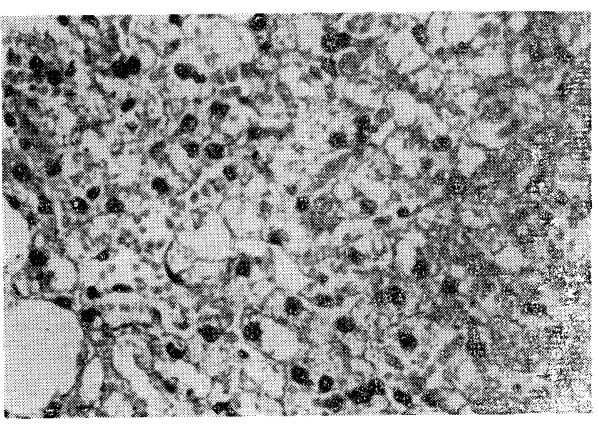

Fig. 24. Pancreatectomized Dog. PAS stain $100 \times$

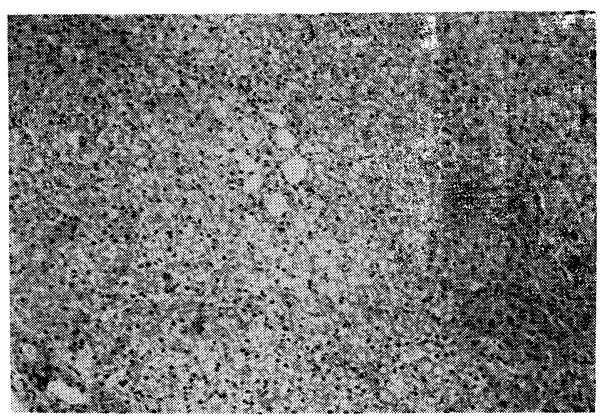

㬰験的糖尿病犬に関する研究は極めて多数みら れるが血管障害との関連について論及したものは 甚だ少ない. Chaikoff ら ${ }^{13)}$ は 5 年間飼育した二匹 の膵摘犬で Artheriosclerosis を認めていない.

Allen $ら^{14)}$ も膵垔全摘をして12年間毎日インス リン30〜40単位注射し control した糖疗病犬につ いて剖検し大動脈, 粲, 網膜に変化のみられなか つた事を報告している。一方 Lukens，Dohan ${ }^{15}$ 及 び Conn ${ }^{16)}$ らは Metapituitary 糖尿病犬を 5 年 間極めて uncontrol の状態下に飼育し Glomerulosclerosis をみとめている. Dragstedt ${ }^{17}$ も膵全摘 後 9 ケ月の剖検で, 正常犬で $1.2 \%$ に, インスリン で維持した膵全摘犬では15\%に Arteriosclerosis を認め亜全摘犬ではそれより稍々少なかつたと報告しているが犬の年令については記載していない. Henry ${ }^{18)}$ らは Atheromatous type より fibrousな type の軽い Atherosclerosis を contrcl の良い全摘犬では31\% に control の悪い膵全摘犬では $63 \%$ に，対照犬では $100 \%$ に認めているが刘照犬は膵摘犬より 3 年以上長く 生存したものであつた。 その際4.5年以内に死んだ膵摘犬について contrclの良否でみた埸合, control の良 かつた糖尿病犬では 7 例中 1 例に Arteriosclerosis を認めたに反し，Contrcl の覀い糖疗病犬では11例中 5 例に Arteriosclerosis をみたという。

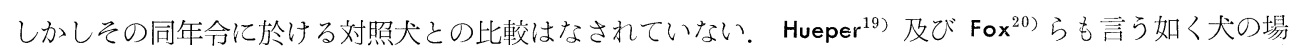
合 5 才以上の成犬では Arteriosclerosis の自然発症も当然考慮されねばならないであろう。

著者が特に 4 才以下の成犬を選び動脈硬化の自然発症の要因を除外するてとに努めた所以である.

扱て本実験の如く高脂肪食投与 8 ケ月という比較的長期の飼育による膵摘犬では大動脈の内膜下浮腫, 粗 造下等の初期硬化像を認めた。特に一部では中膜に於ける硝子化と石灰化がみられ，人体に於ける，所謂 Mencke-berg 型に相当する像がみられた。更に一部では，心筋内小動脈に硬化像と管腔㹨窄が認められ EGG で ST, T の異常即ち冠硬化が50\%にみられた.

之に対し対照犬では同一の高脂肪食投与に拘らず，殆んどてれらの異常が認められなかつたてとより，血 管障害の発生には膵全摘特にインスリン欠乏が，直接に関与していると考えられる.

他方 Chaikoff 及び Allen ${ }^{13)}$ らの如く膵摘犬では動脈硬化をみないという報告は少なくない.しかるに本 
実験で 5 〜 ケ月後に Arteriosclerosis を認めることの出来た原因は，インスリン欠乏と共に高脂肪食投与 による脂質代謝異常か滵接なる関係を有すると考えられる。近年に於ける各種代謝検索法の目ざましい進歩 は種々の異諭にも拘らず，脂質代謝異常が動脈硬化の発生に一つの重要な母子である事が溸次明らかにされ つつある，糖尿病に於いて高脂血症，高コレステロール血症のみられることは周知の事奏である，Adlersb$\mathrm{erg}^{21)}$ Duff ${ }^{22)}$ らは糖尿病動物に高脂血症を Goldner, ${ }^{23)}$ Kendall ${ }^{24)}$ らはアロキサン糖尿病犬に血中脂質の増加 を報告している。 又 Adlersberg ${ }^{25}$ ) は血管合併症を伴い空腹時血糖值 $150 \mathrm{mg} / \mathrm{dl}$ 以上の糖尿病患者では脂酸 及び Triglycerides の増加が特徵的でコレステロール及び燐脂質の増加は軽度であるとしている，Albrink ${ }^{26)}$ らによれば血管障害を有する患者の Triglyceride 值は, 合併症を有しないものに比し高值を示すが，コレ ステロール值には有意の差は無かつたと言う。Barach ら ${ }^{27)}$ は血管障害のある糖㽷病患者は，血管障害を有 しない者より高コレステロール值を示すとしている。一方てれらとは別に血清脂質の増加に動脈硬化発症上 一次的意義を認めないものも少なくない，例えば Duff ら ${ }^{22}$ はアロキサン糖尿病家鬼に於いて，高コレステ ロール血症は認められたが，帮状硬化症は認められなかつた事より，高コレステロール血症は䉼状硬化の唯 一の要素ではないという. 又 Introzzi ら $\left.{ }^{28}\right)$ とれば Arteriosclerosis 合併例と非合併例との間には, 血清

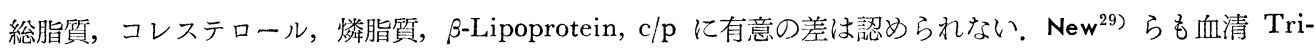
glyceride 值は31〜50才の糖尿病患者血管合例例では, 非合併例より上昇しているが，糖尿病患者の大部分 を占める51才以上の老人，及び30才以下の若年者では，血管障害の有無と関係なく，更にコレステロールは 全年令を通じて，血管合併症の有䍢との間に，有意の相関を認め得なかつたとしている．然るに，私の実験 によれば，高脂肪食投与の腈全摘犬に於ける血清脂質の変動をみると，同しく高脂肪食を投与した対照犬に 比して，著明な高コレステロール血症，NEFA の上昇，脂質燐の上昇が認められ，乙の溹全摘犬に於ける 動脈硬化の発症の一因として，脂質代謝異常による高脂血症が，重要な役割を果しているものと推察出来る. 一方膵覀全摘犬では丽糖能で明らかに糖尿病状態を㴓めるが，高脂肪食投与後も高脂血症はみられなかつた ことより，全摘犬に於ける脂質代謝異常もインスリン欠乏に由来するものと考えるべきであろう。実際にて れら膵全摘犬の血中イ量測定により，血中 ILA の絶対的欠泛を立証し得た.

当教室の成續 ${ }^{30}$ によれば血管合併症を有しない患者群では血中 ILA の低值のものは全く認めない. これ に反して心電図異常, 網膜症, 腎症などの血管合併症の種類と程度の増加に伴い，血中 ILA の低值の者が 多く高值のものが減少する. Kimmelstiel-Wilson 症候群の患者に於いては最も顕著である. 又若年性糖尿 病患者に於いても，その体型を問わず血管合併症を伴うものは血中 ILA が甚だ少ない. 更に血管障害を有 するものの中でも，脂質代謝異常のあるものでは，脂筫正常群より血中 ILA の低い傾向を示す. Rodriguez ${ }^{31}$ はアロキサン糖尿ラット，膵两全摘糖㽷ラットの腎症はインスリンで予防し得るとした。 Bornstein ら ${ }^{32}$ は血管合併症を有する糖尿病患者では合併症を有しないものに比して血中インスリン拮抗因子が特に著明に 梕められるとし，Duncan ら ${ }^{33}$ はインスリン久そとそ腎症，網膜合併症の最大原因であるとした。

更に Rifkin ${ }^{34)}$ はインスリン治療により血管合併症を有する糖尿病患者の代謝異常か改善されることより， 糖尿病血管合併症の成因に，インスリンが直接或いは間接に原因していると述べている．ての事は私の実験 成績に於いて，膵全摘大をインスリン欠乏の状態で長期間飼育すると，動脈硬化症の発生を認め得た事と符 合しており，糖㽷病時の血管合併症の発生に，インスリン欠乏が重要な母子の一つで有る事を暗示している.

一方糖尿病に於いて，高エネルギー燐酸代謝の障害のあるてとは確実であり，それに伴つて $\mathrm{VB}_{1} \mathrm{~B}_{6}$ 等ビ タミンの活性化障害の存在が推定される。Foa ら ${ }^{35}$ は正常大に注射された VB $\mathrm{V}_{1}$ は直ちに燐酸化されるが， 膵摘犬ではこの燐酸化が障害され，乙の障害はインスリン投与により恢復すること，Alloxan 糖尿病犬に於 いて低下した $\mathrm{VB}_{1}$ 附燐能がインスリン投与で恢復するてとを報告しており, 哣田 ${ }^{36}$ も又, 膵摘大の肝内 $\mathrm{VB}_{1}$ 量の変動から, 燐酸化能の著減及びそのインスリン投与による恢復を報告している。須用 ${ }^{37}$ は $\mathrm{VB}_{6}$ も 又生体内で活性化され，ピリドキサール燐酸となるが，乙の活性化の祭に ATP が必要であるという。従 つてピリドキシン負荷後のピリドキサール燐酸の消長を追及することにより, 高エネルギー燐酸代謝と同時 に $\mathrm{VB}_{6}$ 欠乏状態の存否が推定出来る. 高橋 ${ }^{38)}$ は膵摘犬で血中 $\mathrm{VB}_{6}$ 量の減少, GOT, GPT の活性低下を 
認め，インスリン投与による正常化を報告している，私は除膵後96時間ではピリドキシン負荷後の附燐障害 及びそのインスリン投与による活性化能の恢復を鯰めた。しかるに除膵後 8 ケ月以上経過した時には $\mathrm{VB}_{6}$ 活性化能の低下はインスリン投与によつても恢復され得なかつた。

私共の教室 ${ }^{39}$ では長期間 $\mathrm{VB}_{6}$ 欠乏下に飼育した幼若猿に関する研究に於いても， $\mathrm{VB}_{6}$ 欠乏が動脈硬化 症に重要な位置を占めているてと恋めた。糖尿病と $\mathrm{VB}_{6}$ との間には密接な関係があり, 小出 ${ }^{40)} 2$ ケ月 前後の $\mathrm{VB}_{6}$ 欠乏白ネズミ及び 9 ケ月前後の長期 $\mathrm{VB}_{6}$ 欠乏白ネズミに於いて高血糖及び尿糖を認めるが, 前者での血中 ILA は高くインスリン利用障害型糖尿病に類似し，後者では血中 ILA は減少し人のインス リン欠乏型糖尿病と一致する，何れの場合も耐糖曲線は糖尿病状態を呈しインスリン感受性の減弱を認めた ととを報告している.

私の実験に於いて膵摘犬に於ける動脈硬化症の発症にもインスリン欠乏による $\mathrm{VB}_{6}$ 活性化能の著明な低 下か認められており，乙れらの事実より，糖尿病時のインスリンの欠乏が $\mathrm{VB}_{6}$ との関連に於いて，間接的 に動脈硬化症の発症に影響を及ぼしているととも考えられる。更に前記高エネルギー燐酸の不足は主として Krebscycle の不円滑に基づくが，乙の事自体が動脈硬化症の原因となる事は，新井ら ${ }^{41} の$ 主張であり，乙 れまた糖尿病時の動脈硬化症の発症に好適な場を提供するものであろう.

次に糖尿病と肝疾患の相互関係については従来より多数の報告があるがその成績は必ずしも一致していな い. Meade ${ }^{42)}$ とよれば糖尿病時には高頻度に脂肪肝の合併するてとが報告されており，Goodman ${ }^{43}$ (は糖尿 病のコントロール良好な症例では，9％に肝腫大を認めるのみであるが，コントロール不良群では，60\%に 極めて高率に，又ヶトージスの続いた場合100\%に肝腫大を羿めたといい，乙の肝腫大の原因は，脂肪肝に よるものであるとしている。乙の脂肪肝発生頻度は, 報告者により夫々異なり, Robbins ${ }^{44)}$ は50\% Jimmerman

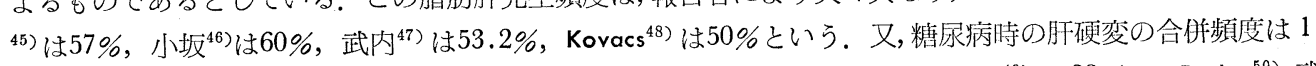
\%から30\%と非常に大きな差がみられる。例えば Joslini1)によれば0.7\%に，Kalk ${ }^{19}$ は $32 \%$ 亿 Poche, ${ }^{50)}$ 武 内 ${ }^{47}$ らは10.6\%に，小坂ら ${ }^{46}$ は $24 \%$ 亿認めるという。乙れら脂肪肝, 肞硬変の合併頻度の差異は, 対照とした 糖尿病患者に依ると思われるが糖尿病に脂肪肝及び肝硬変の合併することは注目に価する。乙の糖尿病にみ られる脂肪肝が，肝硬変に移行するととは，Connor, ${ }^{51)}$ Chaikof ${ }^{52)}$ 及び Popper ${ }^{53)}$ 等によつて既に指摘せら れており, 最近 Kalk ${ }^{49}$ は は糖尿病患者の肝生検により脂肪肝及び肝硬変との間に夫々移行型を認め脂肪肝よ り肝硬変に移行するととを明確に諭説した，又 Jaques $5^{54)}$ を糖尿病にみられる脂肪朋の肝硬変への行程を 説明し脂肪肝の時期に適当な治療をすれば肝硬変への移行を防ぐばかりでなく脂肪肺も改善されるとしてい る.

脂肪肝より移行する肝硬変は門脈性肝硬変の像を示すのが通常であるが Popper ${ }^{53}$ は壊死後性:肝硬変は門 脈性肝硬変の終末像であると述べている。他方 Mc Donald ${ }^{55)}$ は糖尿病患者に燷死後性肝硬変の多くみられ るととを報告した。

私共の教室の成績 ${ }^{56}$ 亿よれば糖尿病患者 65 例の肝生検所見で肝硬変の合併は13例, 肝線維症を合併したも のは14例で両者合計 $41 \%$ である. 又脂肪肝を合併したものは 30 例 $46 \%$ にみられたが，正常肝は 8 例に過ぎな かつた。私の実験成績によれば，膵摘大の肝機能検查で $44 \%$ 亿何らかの異常を認め，且つ組織学的に，肝小 葉中心性又はビマン性脂肪沈着, 肝細胞索の不整を, 又一部には出血壊死像を言めた。このととょり糖尿病 状態に於ける肝硬変の合併には, 脂肪肝より肝細胞猿死を経て壊死後性肝硬変へ移行するものと理解せられ る.

又血中 ILA と肝生検所見々の関連に就いて，私共の教室の成績 ${ }^{57}$ それば糖尿病患者の肝生検所見で異 常の恋められなかつたものは，血中 ILA は正常值であるのに反し，脂肪肝を有する者の血中 ILA は高值 を, 肝線維症を伴つた者では, 血中 ILA は稍久減少傾向を示し, 肝硬変を合併した者の血中 ILA は明ら かに低值を示す事か認められている。このととはインスリンとの関連に於いて脂肪肝より肝硬変に進展する

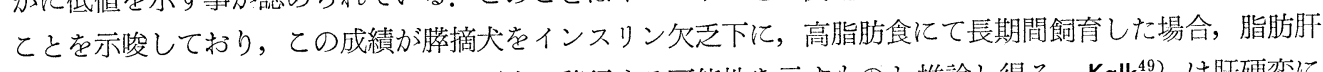
の発生更に肝線維症を経て壊死後性肝硬変へ移行する可能性を示すものと推部し得る。Kalk ${ }^{49}$ ) は肞硬変に 
糖尿病の合併頻度の高いとと, 又, 师の変化は糖层病治療によつて組織学的にある程度可逆性であること, 脂肪肝を伴つた糖尿病前症でその治療によつて糖尿病の発症を減少せしめ得るととを報告している．又 Cajal ${ }^{58)}$ の糖尿病が良好にコントロールされていれば肝機能障害は改善され脂肪沈着もインスリン治療に 良く反応して改善されるとする成縝，或いは Sherlock, ${ }^{59)}$ Jimmerman $^{44)}$ らのインスリン抵抗性と脂肪肝の程 度との間に相関性がみられるという成績等はインスリンの肝障害に対する密接な関連を暗示して興味深い。

即ち糖尿病時の肝障害とインスリン欠乏とは密接な関係が有り糖尿病性脂肪肝或いは肝硬変の発症及び進 展に関してインスリンが直接或いは闑接に重要な役割を演じている事を示唆している。

\section{$\mathrm{V}$ 結 語}

满摘犬を高脂肪食で飼育すると共に糖尿病状態が poor control の状態で而も生命を維持するに要する最 少量のインスリンを投与して 5〜8 ケ月後に血管障害と肝障害の発生を検討して次の成績を得た.

1）膵摘犬に於ては高血糖と共に高脂血症即ちコレステロール，NEFA，血清脂質燐等の上昇が見られる。

2) 膵摘後短期間のものでは $\mathrm{VB}_{6}$ 活性化能の障害を恐めるがインスリンの添加で正常化される．長期間 経過した場合にはインスリンの恢復効果はみられない.

3）膵全摘大では大動脈内膜下浮腫，内膜下粗造化等動脈硬化の初期像に一致する変化を認めた。尚一部 亿心笳内間所血管狭窄像を認めた。

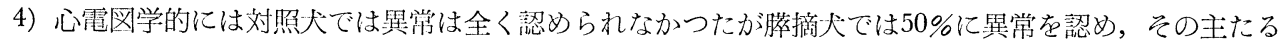
変化は ST, T の変化であつた。

5）膵摘犬の肝機能は高度に障害され組織学的にも高度の脂肪浸潤，肝細胞索の不整，一部には出血壊死 像を垫めたが対照犬では著明な恋化は認めなかつた。

以上の諸成績は実験的糖尿病犬にみられる血管障害及び訮障害の発症，進展にインスリン久乏下の高脂肪 負荷が基本的要因をなすととを示すものである。乙れらの事実は人糖尿病時の血管障害と肝障害の発症に対 しても重要なる意義を有するものと推論される.

稿总終るに臨み御指導と御校閲を賜った恩師山田弘三教授, 御協力頂いた柴田昌雄博士, 坂本信夫博士, 小出忠孝博士，久野勉学士及び糖尿病研究班各位儿御礼申上ます。.

(本論交の要旨は昭和38年第16回日木医学会総会, 第 6 回日本糖尿病学会総会, 国際肝臟研究会日本支部 第 5 回総会に於いて発表した。）

\section{文献}

1) JOSLIN, E.P. : Lea \& Febiger Philaderphia (1959).

2) GOODMAN, J.I., S. WASSERMAN : Am. J. Med. Sci., $220: 30,(1959) . \quad 3)$ BÜRGER. M. : Georg Thieme (Stuttgust), R9, (1954). 4) HINES, E.A., \& N.W. BARKER : Am. J. Med. Sci., $200:$ 717, (1940). 5) LISA, J.R., M. MAGIDARY, and J.E. HART. : J.A.M.A., $118: 1353$, (1942). 6) ROBBINS, S.L., J. ROGERS, and O.J. WALLENMAN : Am. J. Med., $12: 700$, (1952).

7) HAGEDOLN, and JENSEN : Bioch. Ztschr., 46 : 469, (1923). 8) DOLE : J. Clin. Invest., $35: 150$, (1956). 科, $3: 598,(1963)$. 10) FISKE, SABARROW : J.B.C., $66: 375$, (1925). 9) 柴田進：内 化学, $28: 824$, (1957).

12）柴田昌雄：日内分誌，36:93，(1960).

11) 市原 : 生 and KAPLAN : J. Nutrition, $14: 459$, (1937).

14) ALLEN, F.M. and LISA. J.R. : Endocrinology, $46: 282$, (1950). 15) LUKENS, F.D.W. and DOHAN, F.C. : Arch. Path., 41 : 19, (1946). 16) GONN, J.W. : Personal Communication. 17) DRAGSTEDT, L.R. : Biol. Symposia, $11: 118$, (1945). 18) HENRY, T.R., PETERSON, and LINTS : Diabetes, 8 : 298, (1959).

19) HUEPER, W.C. : Arch. Path., 39 : 375, (1945). 20) FOX, H. : edited by 
E.V. Cowdry, New York, The Macmillan Company, (1933).

21) ADLERSBERG, D : Science, $130: 126$, (1959)

22) DUFF, G.L. : J. Exp. Med., 89 : 611, (1949).

23) GOLDNER,

M.G. : Endocrinology, 33 : 297, (1943).

24) KENDALL, F.E. : Proc. Soc. Exp. Biol \& Med.,

$80: 190$, (1945).

25) ADLERSBERG, A.D. : J.A.M.A, $170: 1261$, (1959).

26) ALB-

RINK, M.J. : Ann. Int. Med., 58 : 305, (1963). $\quad 27)$ BARAGH, J.H. : Diabetes., $1: 441$, (1952).

28) INTROZZI, P. BERNASCONI, G. \& BUSCARINI, K. : Acta. Med. Scand., $160: 47$, (1958).

29) NEW, M.I., ROBERTS, T.N., BIERMAN, E.L., and READER, G.G. : Diabetes., 12 : 208, (1963).

30) 山田弘三，他：日内科誌，52：1200，(1964). 31) RODRIQUEZ, R.R. : Rev. Asoc. Med. Arg., $70: 118$, (1956). 32) BORNSTEIN, J. and HYDE, D. : Diabetes, $8: 92$, (1959) 33)

DUNCAN, L. J.P., Mc, FARLANE, A. and ROBSON, J.S. : Lancet., $3: 822$, (1958). 34)

RIFKIN, H. : Diabetes, $12: 31$, (1963). 35) FOA : Arch. Biochem., $13: 449$, (1947). 36)

薗田：ビタミン，14：48，(1958)。須田：酵素化学の進歩：第 1 集 (1949). 38) 高橋：

糖尿病， $4: 58 ，(1961)$ 。 39) 山田弘三, 葛谷文男 : 第 4 回日本老年医学会討議記録 : 92, (1963).

40）小出忠孝, 日内分誌, $38: 4,(1962)$ ４４）新井恒人，他：綜合臨床，9:1976，(1960). 42)

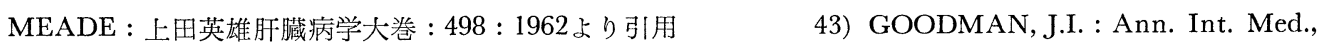
39 : 1077, (1953). 44) ROBBINS, S. : New Engl. J. Med., $231: 865$, (1944). 45) JIMMERMAN, H.J. : J. Lab. \& Clin. Med., $36: 912,922$, (1950). 46) 小坂 : 日本臨床, 19 : 581, (1961). 47) 武内：第 5 回国際肝藏病学会日本医学会総会：(1963). 48) KOVACS, K., and TISZAI : Ztschr. Inn. Med., $15: 1010$, (1960). 49) KALK, H. : Dtsch. Med. Wschr., 42 : 1898, (1959). 50) POCHE, R. : Dtsch. Z. Verdau. u. Stoffwechselkr., $16: 68,(1956)$. 51) CONNOR, C.L. : Ann. J. Path., $14: 347$, (1938). $\quad$ 52) CHAIKOFF, I.L. : Ann. J. Path, 14 : 101, (1938). $\quad$ 53) POPPER : Gastroenterology, $39: 669$, (1960). 54) JAOUES, W.E. : New. Engl. J. Med., $249:$ 442, (1955). 55) Mc.DONALD, R.H. : Am. J. Med., $24: 434$, (1958). 56) 山田弘三, 他 : 第 6 回国際肝㵴病学会, (1964). 57) 山田弘三, 他 : 日内分泌誌, $40: 606$, (1960)。 58) CAJAL, P. : Pres. Med., $58: 1077$, (1958)。現代内科学大系II. p. 55ょ り引用 59) SHERLOGK, S. : Diabetes of the Liver andBiliary System, Black weel, Oxford. p. 431, 2ed, (1958). 